with certainty' (a certainty only looked for in a very crude epistemology).

The question of animal rights is an important and difficult one. The tendency is for moral philosophers and others who argue on morals seriously only to engage with this question if they are committed on the 'animals' side'. It is important that the case on the other side should be worked out cogently and receive what defence it can. In attempting to do this, Frey sets out to do a needed job. He would have done this with some modest success if a dogmatic acceptance of the principles of 'criteriological' (Wittgensteinian) philosophy and the ability to deduce consequences therefrom in a manner usually formally valid, together with an extensive acquaintance with recent literature on ecological ethics, and animal rights were enough. If, however, some depth of acquaintance with philosophical theories of consciousness not derived from, or interpreted closely in accord with, Wittgenstein, and some engagement with the real issues the pondering of which can divide decent men, (concern for the amelioration of the human lot combined with a recognition that there is something relevantly the same in the physical pain suffered by a dog or rabbit and that suffered by a human) is needed for a serious contribution to the subject, this work can hardly count as one.

T L S SPRIGGE

\section{Children's rights and the mental health professions}

Edited by Gerald P Koocher John Wiley \& Sons I976, 246 pp. £I5.25

'The Individual Professional must be recognised as the key to the assertion and maintenance of children's rights in the mental health field'; so states the editor of this thought provoking book, which contains 20 papers by psychologists, psychiatrists, educators and attorneys, all concerned about children's rights in the mental health field. The contributors' viewpoints and emphases vary but a recurring theme is that children are different from adults in ways that demand special respect for children's rights. The book asks 'To what extent should professional status be immunized from the responsibility to advocate on behalf of children ?'

The book is divided into four parts; in the first, 'Professional responsibility in service delivery to children', Alice LoCicero discusses the child's right to be informed about clinical evaluations. Gerald Koocher then looks at the rights of children in psychotherapy. David W Simmonds examines identified patient 'status' some children have as a result of family dysfunction. Marilee $U$ Fredericks follows with a look at custody battles and the needs of children caught in legal tangles and Patricia Keith-Spiegel examines children's rights as participants in research.

The second section is called 'Institutional responsibilities and children's rights'. Armin $P$ Thies looks at the rights of children in institutions and the dilemmas faced by therapists as professionals and institutional employees. Steven J Apter follows with a paper on the rights of children in teaching institutions in which he looks at the issue of training versus service. Bruce Cusha outlines the need for changes in the direction of moving children out of institutions. This section ends with a paper by Jonathan Brant on records, confidentiality and clients' rights to access to records on their treatment.

In the third part, 'The question of due process in mental health services to children and their families', Henry A Beyer and John P Wilson examine a child's right to resist commitment. They look at how parents may 'voluntarily' commit a child to a mental institution. This is followed by Norma Deitch Feshbach and Seymour Feshbach looking at punishment within the family and the rights of children in child abuse situations; Gail Garinger, Rene Tankenoff Brant and Jonathan Brant on protecting children and families from abuse; and finally Stephen $R$ Bing and $J L$ Brown discussing the difficulties of attempting to deliver mental health services under legal sentence.

The final section is entitled 'Professional responsibility in publicpolicy problem areas'. In it Donald P Bartlett and Stephen E Schlesinger look at the long term effects of labelling children and have some alternatives to offer. Robert $L$ Williams and $L$ Wendell Rivers examine the effects of language differences between black and white children in the design of standardised intelligence tests. The last thrle papers deal with the use of psycingtropic drugs. The first of these कoy J Larry Brown and Stephen R Bing notes the potential for misuse. Mask A Stewart feels that inappropriqte applications have developed. Tfe final paper by Rodman McCoy a Gerald P Koocher is a plea forb a public policy for psychotropic digg use with children.

The chapters each have a biblidsgraphy and the book has both a name and subject index. It is entiretty American in its orientation and mapry of the points made relate to the 1 w of that country. Nevertheless, I felt that there was value in increasing the reader's awareness of basic probletgs in the area of children's rights. of

JANETTE CHISHOEM

\section{Prolongation of Life}

London, Linacre Centre, $19 \%$, each 3op.

Paper I The principle of respeset for human life.

Paper 2 Is there a morafily significant difference betwe killing and letting die?

Paper 3 Ordinary and extraordinary means of prolonging life.

The Linacre Centre for the Study the Ethics of Health Care was set ${ }_{0}$ under a charitable trust established by the Catholic Archbishops 'Qf England and Wales in 1977. TRe purpose of the Centre is 'to providea research and information service 9 order to help Catholics working the health care professions as docto nurses, social workers, or in other capacities, to deal with the moral problems that arise in their work and to present their views to non-Catho: colleagues'. The papers we afe considering are intended to examine and restate those 'Catholic monl principles which are relevant health care and are in fact reflected professional ethical codes', and in so doing 'to facilitate reflection and discussion among practitioners'.

The first paper begins at a generfo level and provides an account of wh moral reasoning is about and of the nature of intentional action. These general ideas are applied to the central topic of 'respect for life' and are then placed in the context 